\title{
Dynamics of Insulin Release and
}

\section{Microtubular-Microfilamentous System}

\section{EFFECT OF CYTOCHALASIN B}

\author{
E. Van Obberghen, G. Somers, G. Devis, G. D. Vaughan, \\ F. Malaisse-Lagae, L. Orci, and W. J. Malaisse
}

From the Laboratory of Experimental Medicine, Vrije Universiteit Brussel and Université Libre de Bruxelles, Brussels, Belgium and Institutes of Histology and Biochimie Clinique, Université de Genève, Geneva, Switzerland

A B S T R A C T In order to assess the participation of the microfilamentous cell web in the multiphasic response of the pancreatic beta cell, the effect of cytochalasin B upon both glucose- and sulfonylurea-induced insulin release was investigated in the perfused isolated pancreas. Cytochalasin B failed to affect the basal rate of insulin release, but enhanced the initial and later phases of insulin secretion in response to either glucose or gliclazide. In addition, cytochalasin B lowered the threshold concentration for the stimulant action of glucose upon insulin release. Ultrastructural studies supported the concept of a specific interaction of cytochalasin B with the microfilamentous cell web of the beta cell. It is concluded that the integrity of such a structure is equally important for both the initial and later secretory responses of the beta cell to various insulinotropic agents.

\section{INTRODUCTION}

Recent studies suggest that a double system of microtubules and microfilaments is involved in the secretion of insulin by the pancreatic beta cell, (1-3). First postulated by Lacy, Howell, Young, and Fink (4), the participation of this system in insulin release was documented by investigations on the influence of mitotic spindle inhibitors (colchicine, vincristine), microtubule stabilizers $\left(\mathrm{D}_{2} \mathrm{O}\right.$, hexylene-glycol), and a microfilament modifier (cytochalasin B) upon insulin secretion in vitro. Mitotic spindle inhibitors and microtubule stabilizers were found

Dr. Van Obberghen is a Research Fellow of the Nationaal Fonds voor Wetenschappelijk Onderzoek (Brussels, Belgium).

Received for publication 26 July 1972 and in revised form 20 November 1972. to inhibit the release of insulin evoked by glucose, leucine, theophylline, or sulfonylureas, suggesting that microtubules might govern the migration of secretory granules towards the cell membrane $(1,2,5-7)$. Cytochalasin B, which affects the microfilamentous cell web, was found to facilitate insulin release in response to glucose, theophylline, or sulfonylurea, suggesting that the cell web might act as a barrier controlling the access of secretory granules to the cell membrane $(3,8)$.

In these previous studies the influence of microtubule and microfilament modifiers on insulin secretion was established over prolonged incubation (60 min or more) of either pieces of pancreatic tissue or isolated islets of Langerhans. It remained, therefore, to be investigated whether the microtubular-microfilamentous system is also actively involved in the initial secretory response of the beta cell to different insulinotropic agents. In this first report we have examined the influence of cytochalasin $B$ upon both glucose- and sulfonylurea-induced insulin release by the isolated perfused pancreas. The latter technique was selected for the present experiments because it represents an appropriate model for studies on the dynamic aspects of insulin secretion (9-11). Preliminary results were presented in an abstract form (12).

\section{METHODS}

Surgical procedure. Fully fed male albino rats $(220-300$ $\mathrm{g}$, body weight) were anesthetized with sodium pentobarbital. Oxygen was supplied via a facemask throughout the surgical procedure (approximately $30 \mathrm{~min}$ ). The pancreas was dissected according to the technique described by Sussman, Vaughan, and Timmer (13). After all connections with the adjacent organs had been separated, a first canula was placed in the thoracic aorta just above the coeliac axis, a saline infusion under a pressure of $10 \mathrm{~mm} \mathrm{Hg}$ being initi- 

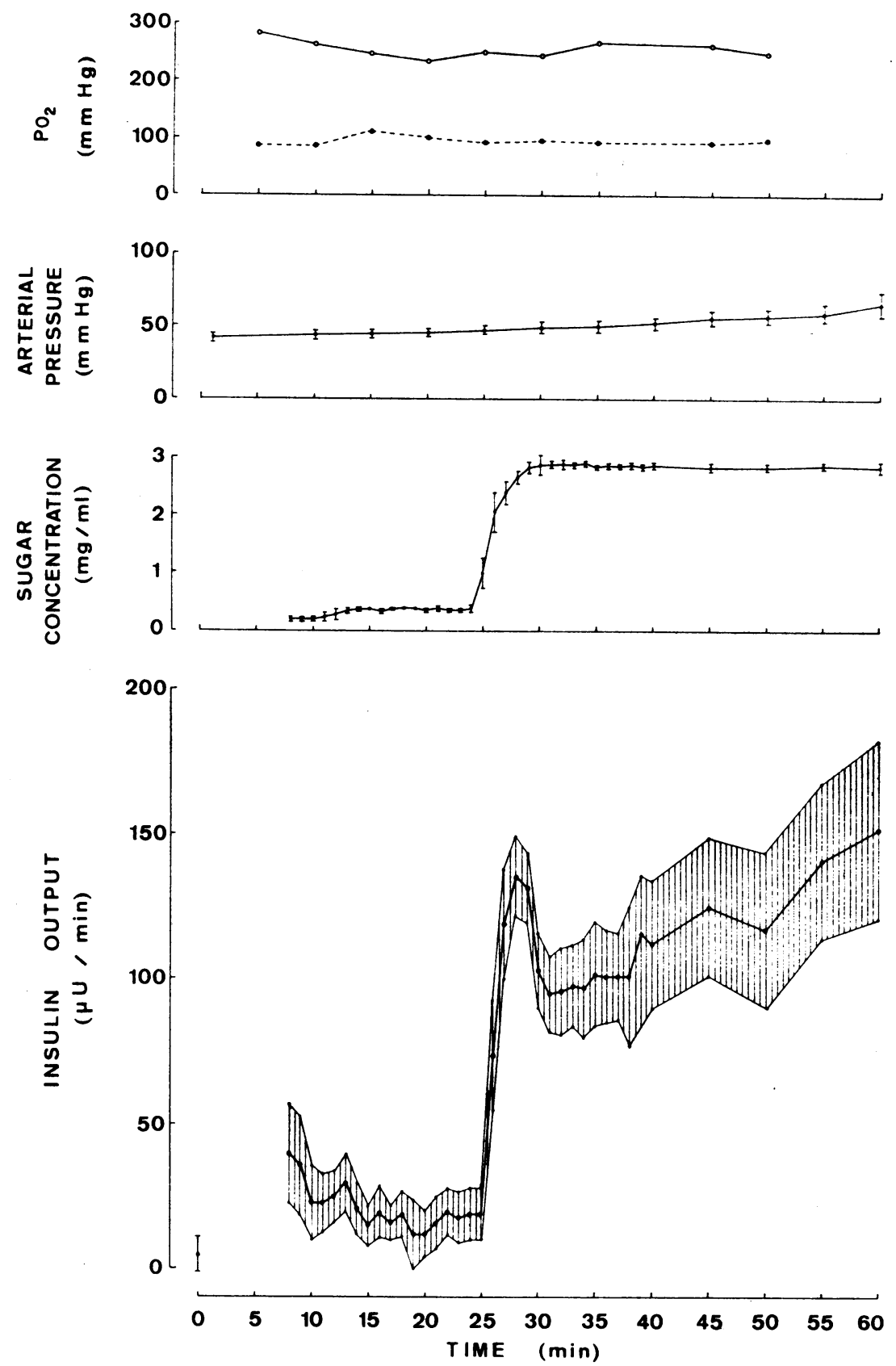

Figure 1 Effect of glucose upon insulin release in the isolated perfused pancreas. From top to bottom are depicted (top panel) the arterial and venous oxygen tensions in a typical experiment; (top middle) the mean $( \pm \mathrm{SEM})$ arterial pressure $(n=17)$; (bottom middle) the mean $( \pm \mathrm{SEM})$ sugar concentration in the extracellular phase of the venous effluent $(n=9)$; and (bottom panel) the mean $( \pm \mathrm{SEM})$ insulin output $(n=17)$.

ated immediately in order to perfuse the pancreas and the remaining part of the duodenum. A second canula was placed in the portal vein and directed towards the pancreas in order to collect the venous effluent. The pancreas was then placed in a perfusion chamber containing saline at $37^{\circ} \mathrm{C}$ and was immediately submitted to perfusion. In this procedure the total period of pancreatic anoxia did not exceed 4 min.
Perfusion procedure. The perfusate consisted of a bicarbonate-buffered medium (14) containing bovine albumin (40 $\mathrm{mg} / \mathrm{ml}$; Fraction V, Sigma Chemical Co., St. Louis, Mo.), and was equilibrated against a mixture of $\mathrm{O}_{2}(95 \%)$ and $\mathrm{CO}_{2}(5 \%)$. The perfusate also contained heparinized blood $(10 \%, \mathrm{v} / \mathrm{v})$ obtained by aortic puncture of etheranesthetized rats. The perfusion device consisted of an extracorporeal perfusion unit (Model 1000, Ambec, Boulder, 
Colo.) connected to a pressure indicator (Model 1020, Ambec) via a pressure transducer (Model P23AA, Statham, Hato Rey, Puerto Rico). The perfusate was circulated through the perfusion unit for $15-30 \mathrm{~min}$ at $37^{\circ} \mathrm{C}$ before introducing the isolated pancreas (time zero). Thereafter and for the rest of the experiment, no recirculation was allowed to occur, the venous effluent being either discarded or collected over individual periods of $1 \mathrm{~min}$ each. The flow rate through the pancreas was maintained constant in all experiments at $2.0 \mathrm{ml} / \mathrm{min}$.

Cytochalasin B (Imperial Chemical Industries, Macclesfield, England) was first dissolved in dimethylsulphoxide $(10 \mathrm{mg} / \mathrm{ml})$ before addition to the perfusate. In all experiments performed with cytochalasin $\mathrm{P}$, this drug was present in the perfusate at a concentration of $0.01 \mathrm{mg} / \mathrm{ml}$ throughout the entire period of perfusion.

In order to raise the glucose concentration, or to add gliclazide (S852, Laboratoires Servier, Paris, France) to the perfusate, small amounts of bicarbonate-buffered solutions containing one or the other of these stimulatory agents were administered into the arterial canula by mean of a Braun pump (B. Braun Apparatebau, Melsungen, Germany) at a flow rate of $0.05 \mathrm{ml} / \mathrm{min}$. The concentration of these solutions was calculated in order to achieve a final concentration of either glucose at $0.5-0.9-1.2$ and $3.0 \mathrm{mg} / \mathrm{ml}$, or gliclazide at $0.02 \mathrm{mg} / \mathrm{ml}$. At this concentration gliclazide, a new sulfonylurea, exerts its maximal insulinotropic action in incubated pieces of rat pancreatic tissue (15). In most experiments the stimulatory agent was added on the arterial side during the 24th $\mathrm{min}$, and maintained, thereafter, up to the end of the experiment. As shown in Fig. 1, a significant increase in the glucose concentration of the venous effluent was not ohserved until the 25 th min sample. It was considered, therefore, that the 25 th min sample represented the first one in which an increase in insulin concentration could be expected. Experiments with cytochalasin $\mathrm{B}$ and control perfusions were carried out on different rats, but usually on the same day, two to eight individual experiments being performed each day.

Chemical detcrminations. The samples of venous effluent were collected in iced tuhes and centrifuged for $20 \mathrm{~min}$ at $4^{\circ} \mathrm{C}$ for deposition of red cells. The supernatant solution was stored at $-25^{\circ} \mathrm{C}$, and later examined for its insulin, glucose, and $\mathrm{K}^{+}$content. Glucose was measured by the method of Hoffman (16) and $\mathrm{K}^{+}$by flame photometric method, both procedures being adapted to the Technicon Autoanalyzer (Technicon Instruments Corp., Tarrytown, N. Y.). Insulin was assayed by a modification of the method described by Wright, Malaisse, and Reynolds (17). The amounts of guinea pig antiinsulin serum $(0.04 \mu 1$ per tube; lot 468 kindly supplied by Dr. P. H. Wright, Indiana University, Indianapolis, Ind.), bovine insulin used as reference $(0-120 \mu \mathrm{U}$ per tube), labeled insulin (90 $\mu \mathrm{U}$ per tube), and cellulose (10 mg per tube) were smaller than those used in the original method, but the respective volumes of each reagent solution were unaltered. These changes did not alter the linear relationship between antibody-bound labeled insulin recovered in the supernatant and unlabeled insulin used for partial neutralization (up to $50 \%$ ) of the antibodies. Each individual measurement was made in duplicate and referred to a standard curve obtained within the same assay.

Ultrastructural studies. At either the 30 th $\mathrm{min}$ or 60 th min of perfusion, the pancreas was injected manually through the arterial canula during 1 min with $2 \mathrm{ml}$ of saline, followed by $4 \mathrm{ml}$ of fixative administered during the next $2 \mathrm{~min}$. The tail of the pancreas was then im-

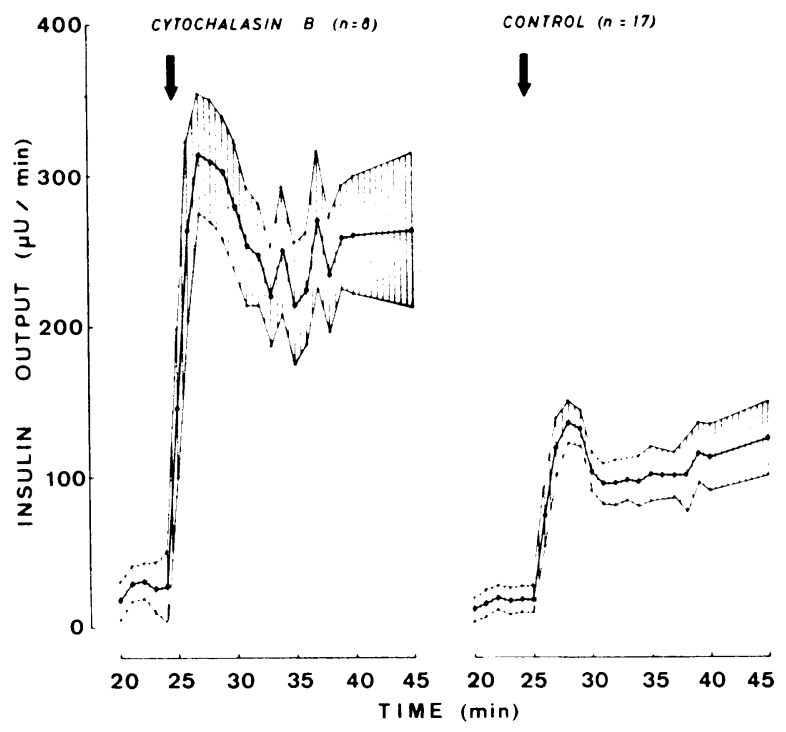

FigrRE 2 Effect of cytochalasin B upon glucose-induced insulin release. Mean values $( \pm \mathrm{SEM})$ are shown together with the number of individual experiments in each group (n). Cytochalasin $\mathrm{B}(0.01 \mathrm{mg} / \mathrm{ml})$ was present throughout the experiment $(0-45$ th $\mathrm{min})$. The glucose concentration was raised from 0.3 to $3.0 \mathrm{mg} / \mathrm{ml}$ at the 25 th min (arrow) and, thereafter, maintained at $3.0 \mathrm{mg} / \mathrm{ml}$ until the end of the experiment.

mersed in the fixative and cut in small pieces. The fixative consisted in a $4.5 \%$ glutaraldehyde solution in phosphate buffer $(0.1 \mathrm{M}, \mathrm{pH} 7.4)$ containing $0.5 \mathrm{mM} \mathrm{CaCl}$. After 36-72 h of immersion in the fixative solution, the pieces of pancreas were extensively washed with the same phosphate huffer, postfixed during $90 \mathrm{~min}$ with $\mathrm{OsO}_{4}$ (in phosphate buffer), dehydrated in gracled alcohols, and embedded in Epon. The whole fixation and dehydration procedure was performed at room temperature. Thin sections of islets were obtained using a LKB microtome (LKB Instruments, Inc., Rockville, Md.) equipped with a diamond knife. They were mounted on uncoated copper grids, sequentially stained with uranyl acetate and lead citrate, and examined with a Philips EM 300 electron microscope (Philips Electronics Instruments, Mount Vernon, N. Y.).

\section{RESULTS}

Control cxperiments. Fig. 1 illustrates the effect of glucose upon insulin release. As the glucose concentration of the perfusate was increased from approximately 0.3 to $3.0 \mathrm{mg} / \mathrm{ml}$, the rate of secretion rapidly increased above its basal value $(10-20 \mu \mathrm{U} / \mathrm{min})$. Thereafter. and despite stable levels of glucose, a multiphasic pattern of insulin release was noticed, analogous to that described by Grodsky: Curry, Bennett, and Rodrigo (9). The arterial pressure steadily increased from $42 \pm 3 \mathrm{~mm} \mathrm{Hg}$ at the outset of the perfusion up to $67 \pm 8 \mathrm{~mm} \mathrm{Hg}$ after $1 \mathrm{hr}$. The oxygen tensions varied between 200 and $300 \mathrm{~mm} \mathrm{Hg}$ on the arterial side, while venous oxygen tensions were in the range of $60-90 \mathrm{~mm} \mathrm{Hg}$. The arteriovenous differ- 

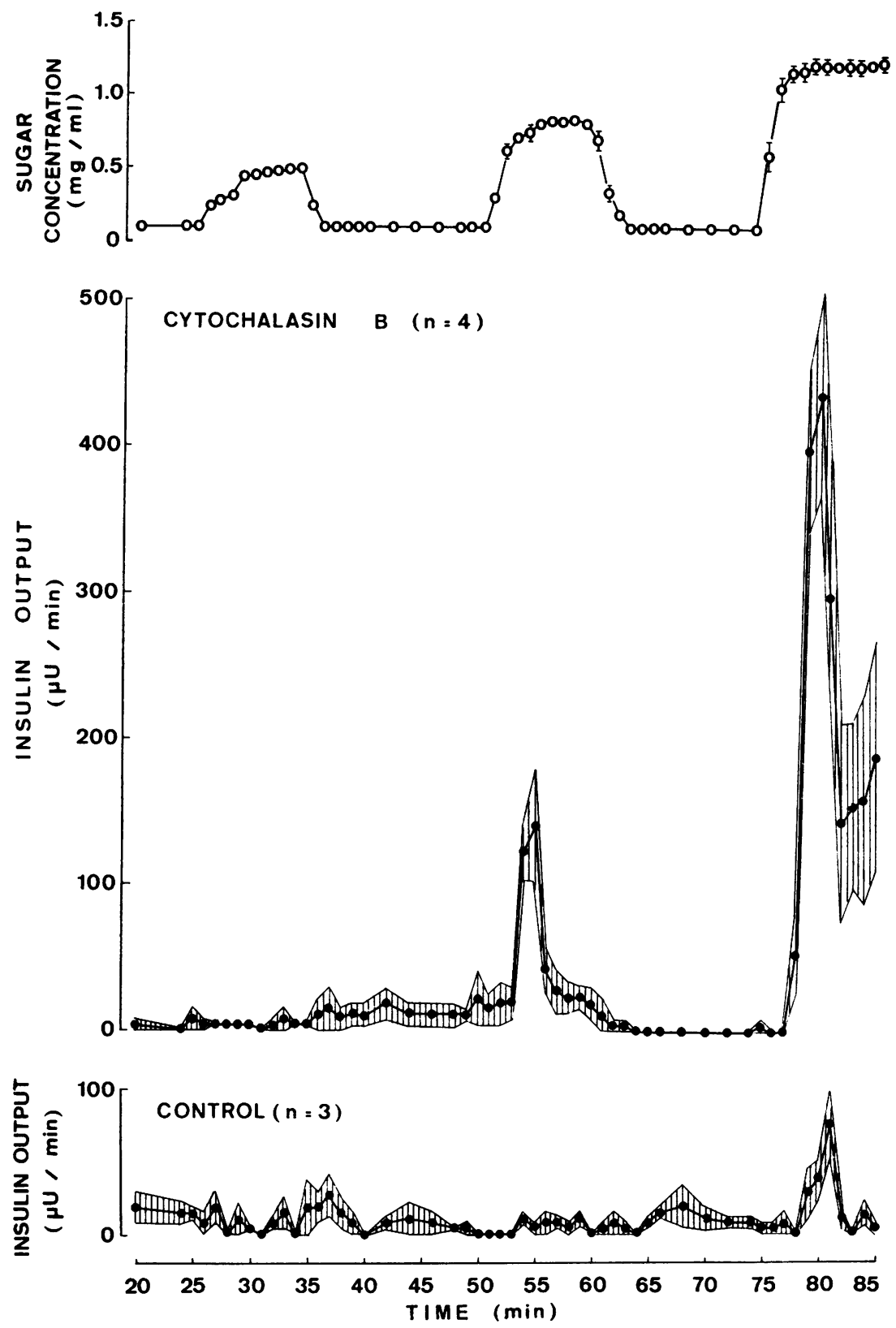

FIGURE 3 Effect of square-waved glucose stimuli upon insulin release in the absence and presence of cytochalasin $B$. The mean $( \pm S E M)$ sugar concentration in the extracellular phase of the venous eiffluent for all experiments $(n=7)$ is shown in the top panel. Mean values ( \pm SEM) for insulin output are shown together with the number of individual experiments in each group $(n)$. Cytochalasin B $(0.01 \mathrm{mg} / \mathrm{ml})$ was present throughout the entire period of perfusion (0-85th $\mathrm{min})$.

ence in $\mathrm{pO}_{2}$ remained fairly constant throughout the experiment (Fig. 1). No hemolysis could be detected, and the $\mathrm{K}^{+}$concentration of the extracellular phase averaged $5.2 \pm 0.3 \mathrm{meq} /$ liter (mean $\pm \mathrm{SD}, n=41$ ). Arterial $\mathrm{pH}$ remained stable throughout the perfusion, between 7.35 and 7.40 .
Effects of cytochalasin $B$ on glucose-induced insulin release. In a preliminary set of experiments, no effect of dimethyl sulfoxide (DMSO) $(1.0 \mu \mathrm{l} / \mathrm{ml}, \mathrm{v} / \mathrm{v})$ upon glucose-induced insulin secretion could be detected. Thus, in the presence of DMSO, the total amount of insulin released between the 25 th and 40 th min averaged $102 \pm 2 \%$

1044 Van Obberghen, Somers, Devis, Vaughan, Malaisse-Lagae, Orci, and Malaisse 
$(n=2)$ of the corresponding control value found in its absence.

As shown in Fig. 2, cytochalasin B did not significantly alter the basal output of insulin observed at a low glucose concentration $(0.3 \mathrm{mg} / \mathrm{ml})$, but markedly enhanced both the initial and later secretory response to a higher glucose level $(3.0 \mathrm{mg} / \mathrm{ml})$. Thus, the initial phase, estimated over a period of $5 \mathrm{~min}$, corresponded to a total release of $1202 \pm 179 \mu \mathrm{U}(n=8)$ in the presence of cytochalasin B and $529 \pm 57 \mu \mathrm{U}(n=17)$ in its absence $(P<0.001)$. The mean individual secretory rates between the 5th and 15th min after the addition of glucose were also significantly higher $(P<0.001)$ in the presence of cytochalasin $\mathrm{B}(267 \pm 45 \mu \mathrm{U} / \mathrm{min}, n=8)$ than in its absence $(103 \pm 15 \mu \mathrm{U} / \mathrm{min}, n=17)$.

Neither in the present nor in the following experiments performed in the presence of cytochalasin B, did the mold metabolite exert any significant effect upon arterial pressure or oxygen tension. Thus, in a series of 16 experiments, arterial pressure averaged $47 \pm 3,50 \pm 3$, $55 \pm 3$, and $57 \pm 3 \mathrm{~mm} \mathrm{Hg}$, respectively, at time zero, 25 , 40 , and $60 \mathrm{~min}$. Arteriovenous differences in $\mathrm{pO}_{2}$ fluctuated between 150 and $180 \mathrm{~mm} \mathrm{Hg}$. These values are comparable to those found in the absence of cytochalasin B (see Fig. 1).

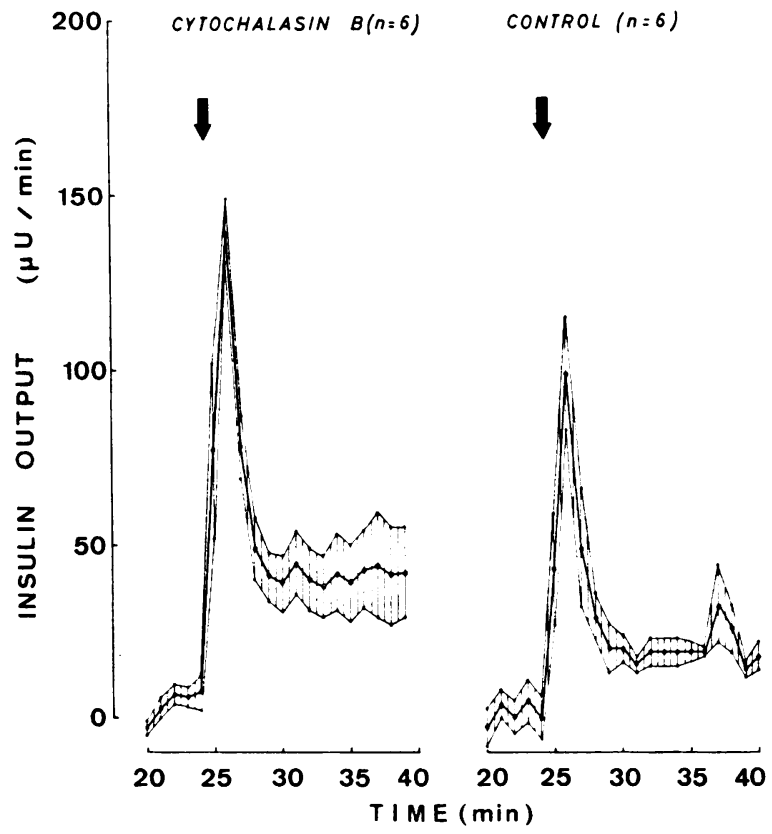

FIGURE 4 Effect of cytochalasin B upon gliclazide-induced insulin release at low glucose concentration $(0.3 \mathrm{mg} / \mathrm{ml})$. Same presentation as is Fig. 2. Cytochalasin B $(0.01 \mathrm{mg} / \mathrm{ml})$ and glucose $(0.3 \mathrm{mg} / \mathrm{ml})$ were present throughout the experiment $(0-40$ th $\mathrm{min})$. Gliclazide $(0.02 \mathrm{mg} / \mathrm{ml})$ was added to the perfusate from the 25th min (arrow) until the end of the experiment.

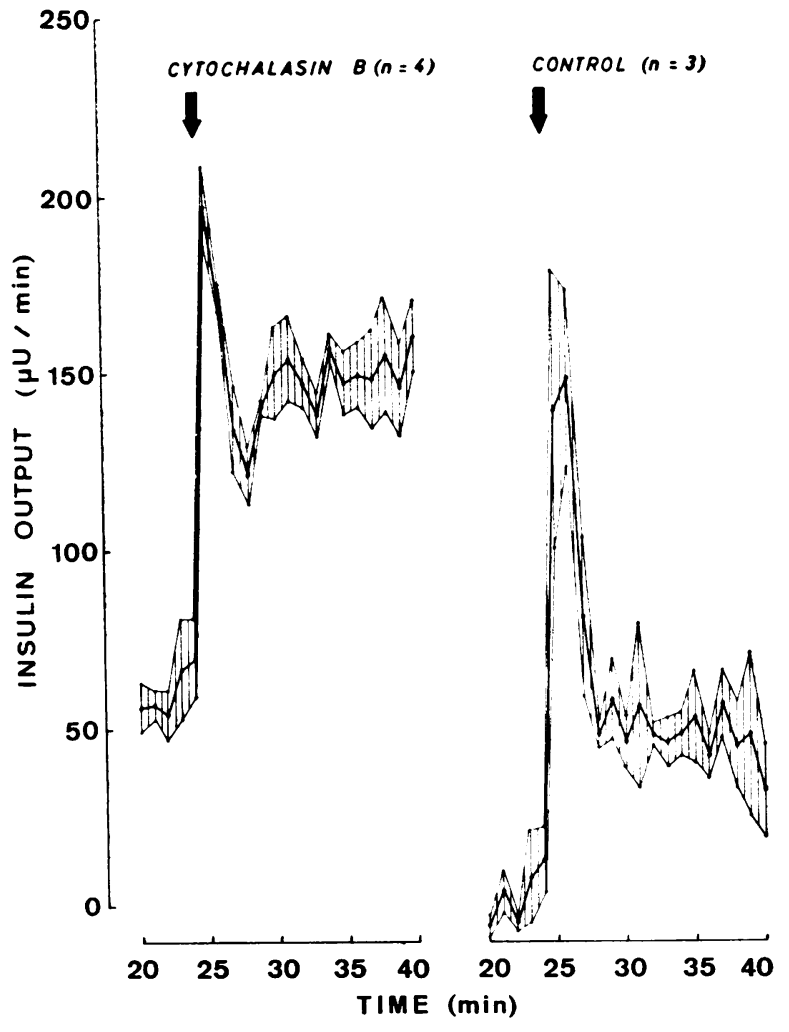

FIGURE 5 Effect of cytochalasin B upon gliclazide-induced insulin release at a glucose concentration of $0.9 \mathrm{mg} / \mathrm{ml}$. Same presentation as in Fig. 2. Cytochalasin B $(0.01 \mathrm{mg} / \mathrm{ml})$ and glucose $(0.9 \mathrm{mg} / \mathrm{ml})$ were present throughout the experiment $(0-40$ th $\mathrm{min})$. Gliclazide $(0.02 \mathrm{mg} / \mathrm{ml})$ was added to the perfusate from the 25th min (arrow) until the end of the experiment.

The effect of cytochalasin B upon insulin release was also investigated at different glucose levels (Fig. 3). In the control experiments, square-waved increases in glucose concentration from a basal value of approximately $0.1 \mathrm{mg} / \mathrm{ml}$ up to 0.5 or $0.8-0.9 \mathrm{mg} / \mathrm{ml}$ failed to affect insulin output which remained constantly close to its basal value. However, when the glucose concentration was raised to $1.2-1.3 \mathrm{mg} / \mathrm{ml}$, a short-lived secretory response occurred, peaking at a value of $76 \pm 23 \mu \mathrm{U} / \mathrm{min}$ $(n=3)$. In the presence of cytochalasin B, no increase in insulin release was observed with the lowest of the glucose loads $(0.5 \mathrm{mg} / \mathrm{ml})$. The second glucose stimulation $(0.8-0.9 \mathrm{mg} / \mathrm{ml})$ provoked an early secretory peak reaching a value of $141 \pm 38 \mu \mathrm{U} / \mathrm{min}$, whereas no obvious secondary rise was noted. In the presence of eytochalasin $\mathrm{B}$, the last and highest glucose stimulus $(1.2-1.3 \mathrm{mg} / \mathrm{ml})$ provoked both a dramatic early response peaking at $437 \pm 68 \mu \mathrm{U} / \mathrm{min}$ and a secondary phase of insulin release averaging $150-190 \mu \mathrm{U} / \mathrm{min}$. It should be noted that some of these values are higher than those found in the presence of cytochalasin B at a higher glu- 

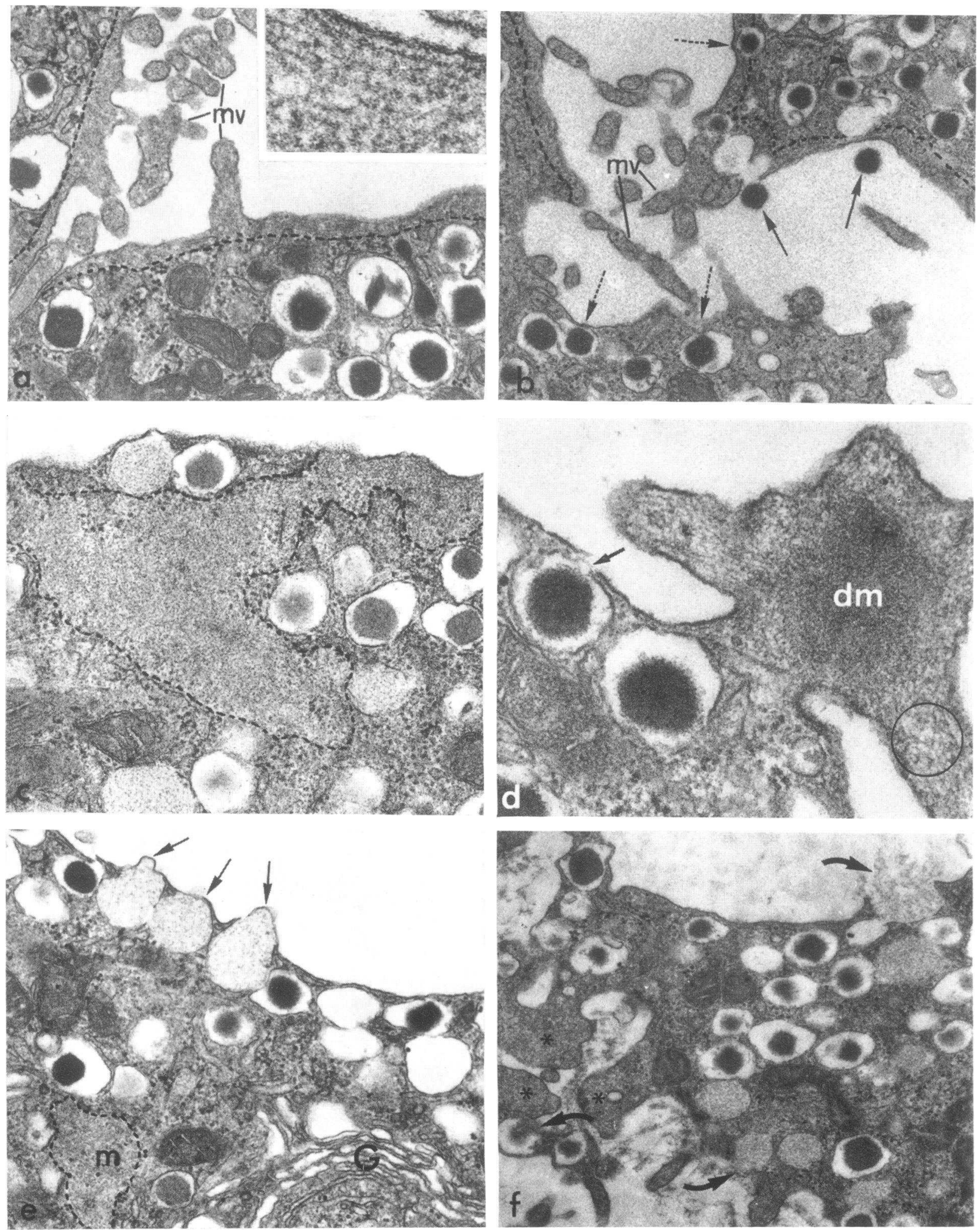

Figure 6 Pancreases examined at the 60th min of perfusion. (a) Pancreas exposed for 25 $\min (0-25$ th $\mathrm{min})$ to a low glucose concentration $(0.3 \mathrm{mg} / \mathrm{ml})$ and, thereafter (25th-60th $\mathrm{min}$ ) to a high glucose concentration $(3.0 \mathrm{mg} / \mathrm{ml})$. Several microvillous processes ( $m v)$ extend in the extracellular space; the cell web is underlined by the dotted line (magnification 
cose concentration $(3.0 \mathrm{mg} \mathrm{ml})$ in previous experiments (Fig. 2). This difference could be due, in part at least, to the fact that the glucose stimuli were applied at different times in the two series of experiments, i.e.. at the 25th (Fig. 2) and 75 th min (Fig. 3), respectively. Indeed, it has been shown by Bergman and Urquhart (18) and confirmed in this laboratory (unpublished observations) that the secretory response of the pancreas to an identical glucose stimulus is much more marked when given during the 2 nd or 3 rd h of perfusion rather than during the 1st h.

Effects of cytoclialasin $B$ on sulfonylurea-induced insulin rclcase. In a first set of experiments, the effect of gliclazide was tested at a glucose concentration ( 0.3 $\mathrm{mg} / \mathrm{ml}$ ) far below the threshold value for glucose-induced insulin release. Under this experimental condition a low level of insulin release was observed in both the absence and presence of cytochalasin $\mathrm{B}$, before the administration of gliclazide (Fig. 4). In the control experiments gliclazicle provoked a brisk early response, followed by a secondary phase during which the rate of insulin secretion was only slightly higher than the basal value. Cytochalasin B significantly increased both the early and later secretory response to gliclazide. Thus, the initial peak observed within the first 5 min after the addition of gliclazide represented a total release of $367 \pm 50 \mu \mathrm{U}(n=$ $6)$ in the presence of cytochalasin B, as distinct from only $226 \pm 22 \mu \mathrm{U}(n=6)$ in its absence $(P<0.03)$. The individual mean secretion rates during the later period (5th-15th min after the addition of gliclazide) were also higher in the presence than in the absence of cytochala$\sin B$, averaging respectively $42 \pm 9$ and $19 \pm 1 \mu \mathrm{C} / \mathrm{min}$ $(n=6$ in each case; $P<0.05$ ).

Since crtochalasin B apparently lowers the threshold value for glucose-induced insulin secretion (Fig. 3), the effect of gliclazide was also tested at a glucose concentration of $0.9 \mathrm{mg} / \mathrm{ml}$, which is indeed close to the normal threshold value for the stimulant action of glucose on insulin release $(14,19)$. It is known that gliclazide, like other sulfonylureas, causes a more marked release of insulin over $60 \mathrm{~min}$ of incubation at such a glucose level than at lower glucose concentrations (15, 20-22). The same phenomenon was observed here. Thus, in the control experiments, both the initial and later responses of the pancreas to gliclazide were higher at the glucose concentration of $0.9 \mathrm{mg} / \mathrm{ml}$ than at that of 0.3 $\mathrm{mg} / \mathrm{ml}$. In the presence of cytochalasin B and before the addition of gliclazide, the rate of secretion evoked by glucose $(0.9 \mathrm{mg} / \mathrm{ml})$ was significantly higher $(P<$ 0.005 ) than that found in the control experiments (Fig. $5)$. The initial response to gliclazide, calculated as the total amount of insulin released over the first 4 min after the addition of the sulfonylurea, was also significantly higher $(P<0.05)$ in the presence of cytochalasin $\mathrm{B}$ $(603 \pm 16 \mu \mathrm{U}, n=4)$ than in its absence $(399 \pm 78 \mu \mathrm{U}$, $n=3$ ). However, due to the high rate of secretion observed in the presence of cytochalasin $B$ before the addition of gliclazide, the increment in secretion rate attributable to the sulfonylurea during the initial phase was of comparable magnitude in the presence and absence of cytochalasin B. During the later phase. i.e. between the 5 th and 15 th min after the addition of gliclazide, both the absolute rates of insulin secretion and the increments in insulin output attributable to the sulfonylurea were signicantly higher in the presence of cytochalasin B than in its absence. During this later phase the absolute rates averaged $150 \pm 8 \mu \mathrm{U} / \mathrm{min}(n=4)$ and $48 \pm 6 \mu \mathrm{U} / \mathrm{min}$ $(n=3)$, respectively, in the presence and absence of cytochalasin B $(P<0.001)$, whereas the gliclazide-induced increments in secretion rate averaged, respectively.

$\times 27,000)$; the insert shows, at higher magnification $(\times 190,000)$ the characteristic microfilamentous network of the cell web. (b) Pancreas exposed for $60 \mathrm{~min}(0-60$ th $\mathrm{min})$ to glucose $(0.9 \mathrm{mg} / \mathrm{ml})$ and for the last $35 \mathrm{~min}$ (25th-60th $\mathrm{min})$ to gliclazide $(0.02 \mathrm{mg} / \mathrm{ml})$. Two granule cores are extruded in the extracellular space (solid arrows); some granules (dotted arrows) are seen in close proximity to the cell membrane (magnification $\times 19,000$ ). (c) Pancreas exposed for $60 \mathrm{~min}(0-60$ th $\mathrm{min})$ to cytochalasin $\mathrm{B}(0.01 \mathrm{mg} / \mathrm{ml})$. The glucose concentration of the perfusate was raised from 0.3 to $3.0 \mathrm{mg} / \mathrm{ml}$ at the $25 \mathrm{th} \mathrm{min}$. A large irregular cytochalasin-induced mass is outlined by the dotted line (magnification $\times 31,000$ ). (d) Pancreas exposed for $60 \mathrm{~min}(0-60 \mathrm{th} \mathrm{min})$ to cytochalasin $\mathrm{B}(0.01 \mathrm{mg} / \mathrm{ml})$ and glucose $(0.9 \mathrm{mg} / \mathrm{ml})$ and for the last $35 \mathrm{~min}$ (25th-60th $\mathrm{min}$ ) to gliclazide $(0.02 \mathrm{mg} / \mathrm{ml})$. A bleb, probably resulting from the collapse of several microvillous processes, shows a characteristic dense mass $(d m)$; the microfilamentous network can be seen in one of the microvillous processes (encircled area); the arrow points to an emiocytotic event (magnification $\times 66,000$ ). (e) Pancreas exposed for $60 \mathrm{~min}(0-60$ th $\mathrm{min})$ to cytochalasin $\mathrm{B}(0.01 \mathrm{mg} / \mathrm{ml})$ and glucose $(0.9 \mathrm{mg} / \mathrm{ml})$ and for the last $35 \mathrm{~min}(25 \mathrm{th}-60 \mathrm{th} \mathrm{min})$ to gliclazide $(0.02 \mathrm{mg} / \mathrm{ml})$. The margination of the secretory granules near the plasma membrane is prominent; the arrows point to pale secretory granules bulging out the cell membrane and probably undergoing extrusion; $m$, cytochalasin-induced mass; $G$, Golgi complex (magnification $\times 23,000)$. $(f)$ Pancreas exposed for $60 \mathrm{~min}(0-60$ th $\mathrm{min})$ to cytochalasin $\mathrm{B}(0.01 \mathrm{mg} / \mathrm{ml})$. The glucose concentration of the perfusate was raised from 0.3 to $3.0 \mathrm{mg} / \mathrm{ml}$ at the $25 \mathrm{th} \mathrm{min}$. Several emiocytotic events can be seen along the cell surface; secretory material being discharged in the extracellular space is indicated by the curved arrows; three cytochalasin-induced masses are also seen (asterisks) (magnification $\times 15,000$ ). 

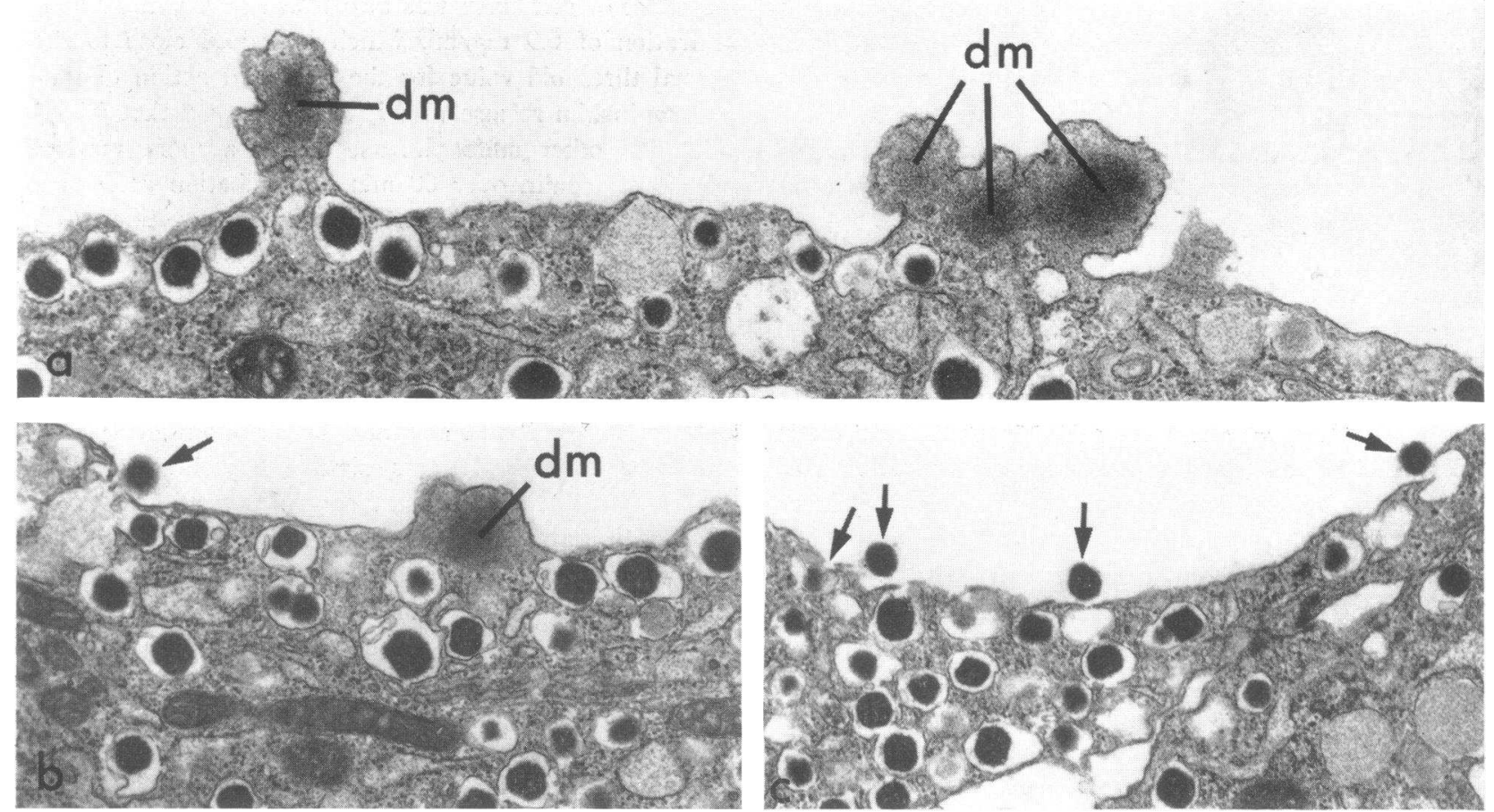

Figure 7 Pancreases examined at the 30 th $\min$ of perfusion. (a) Pancreas exposed for 30 $\min (0-30$ th $\mathrm{min})$ to cytochalasin $B(0.01 \mathrm{mg} / \mathrm{ml})$ and glucose $(0.3 \mathrm{mg} / \mathrm{ml})$. The typical changes induced by cytochalasin $\mathrm{B}$ are present. Localized blebs containing dense masses of microfilamentous material $(d m)$ are seen at various foci at the periphery of the $\mathrm{B}$ cell. Margination of secretory granules towards the plasma membrane is also noted (magnification $\times 20,000)$. (b) Pancreas exposed for $30 \mathrm{~min}(0-30$ th $\mathrm{min})$ to cytochalasin $\mathrm{B}(0.01 \mathrm{mg} / \mathrm{ml})$ and glucose $(0.3 \mathrm{mg} / \mathrm{ml})$ and stimulated for $5 \mathrm{~min}(25 \mathrm{th}-30 \mathrm{th} \mathrm{min})$ with gliclazide (0.02 $\mathrm{mg} / \mathrm{ml})$. Note the presence of a dense mass $(\mathrm{dm})$ and the margination of secretory granules. The arrow points to an emiocytotic site (magnification $\times 17,000)$. (c) Pancreas exposed for $30 \mathrm{~min}(0-30$ th $\mathrm{min})$ to cytochalasin $\mathrm{B}(0.01 \mathrm{mg} / \mathrm{ml})$ and glucose $(0.3 \mathrm{mg} / \mathrm{ml})$, and stimulated for $5 \mathrm{~min}$ (25th-30th $\mathrm{min})$ with gliclazide $(0.02 \mathrm{mg} / \mathrm{ml})$. Several emiocytotic events (arrows) are seen at the periphery of a $\mathrm{B}$ cell (magnification $\times 17,000$ ).

$+89 \pm 5 \mu \mathrm{U} / \mathrm{min}(n=4)$ with cytochalasin $\mathrm{B}$, and $+46 \pm 3 \mu \mathrm{U} / \min (n=3)$ in its absence $(P<0.005)$.

Morphological findings. The ultrastructural appearance of the beta cell in pancreases perfused in the absence of cytochalasin B was well preserved and comparable to that previously described (23). In these control pancreases a band of homogenous cytoplasmic material with varying thickness was seen just beneath the cell membrane, and extended in the core of microvillous processes (Fig. $6 a$ and $b$ ). At high magnification, this cell web $(3,8)$ appeared to consist in a microfilamentous network (insert of Fig. $6 a$ ). In both glucose- and gliclazide-stimulated pancreases, occasional granules could be found free in the extracellular space.

In the islets of pancreases exposed to cytochalasin B, the extracellular space was markedly enlarged, whilst the beta cells exhibited striking changes of their shape. The microfilaments accumulated in either roundish clumps of densely packed material or in large masses extending far into the cytoplasm. Between these masses the secretory granules were found to marginate towards the plasma membrane. They frequently protruded at the cell surface and, in some instances, their content seemed to spill in the extracellular space. Emiocytotic figures were also often seen in close proximity to the microfilamentous masses (Fig. $6 c-f$ ). It should be underlined that the typical changes induced by cytochalasin $B$ in the stucture of the cell web were already present at the time of the early secretory response (25th-30th $\mathrm{min}$ ) which follows the sudden exposure of the pancreas to either elevated levels of glucose or to gliclazide. Indeed, as shown in Fig. 7, pancreases examined at the 30th min disclosed the presence of dense masses of microfilamentous material and the margination of secretory granules towards the cell membrane. At that time (30th $\mathrm{min}$ ) figures of emiocytosis were very rare when the pancreas 
had not been exposed to any stimulus (Fig. $7 a$ ), and much more frequent when gliclazide had been administered from the 25 th to 30 th min (Fig. $7 b$ and $c$ ).

\section{DISCUSSION}

The data illustrated in Fig. 1 indicate that our preparation of isolated perfused pancreas responded to glucose stimulation in a multiphasic manner comparable to that first described by Grodsky et al. (9). The pattern of insulin response to sulfonylurea, characterized by a shortlived initial response and a modest secondary insulinotropic action, is also in good agreement with previously published data (9-11). Moreover, in our experiments, the relative order of magnitude for the rates of insulin secretion during either the initial or late phase, in response to increasing glucose concentrations and various combinations of glucose and sulfonylurea, was comparable to that reported in previous studies with either the isolated perfused pancreas, pieces of pancreatic tissue, or isolated islets of Langerhans (7, 9-11, 15, 19, 20-22). These findings and the ultrastructural appearance of the beta cell in control experiments suggest that we are dealing with a reliable preparation in good functional state.

Cytochalasin B did not affect the basal rate of insulin release observed at a low glucose concentration $(0.3 \mathrm{mg} /$ $\mathrm{ml}$ ), and significantly enhanced both the early and late release of insulin evoked by glucose in a higher concentration $(3.0 \mathrm{mg} / \mathrm{ml})$. These findings illustrated in Fig. 2 support the concept that cytochalasin B facilitates, but does not provoke insulin secretion (3).

The results illustrated in Fig. 3 suggest that cytochalasin B alters the sensitivity of the beta cell to glucose. In this and other in vitro systems $(14,19)$, the threshold value for the stimulant action of glucose upon insulin release is close to $1.0 \mathrm{mg} / \mathrm{ml}$. As already demonstrated by Grodsky (24), glucose concentrations (1.2$1.3 \mathrm{mg} / \mathrm{ml}$ ) which are only slightly in excess of such a threshold value provoke an early secretory response but little, if any, secondary release of insulin (Fig. 3). In the presence of cytochalasin $\mathrm{B}$, a secretory response analogous to that usually found at a glucose concentration of $1.2-1.3 \mathrm{mg} / \mathrm{ml}$ was already observed at a level of $0.8-0.9 \mathrm{mg} / \mathrm{ml}$. Moreover, in the presence of cytochalasin $\mathrm{B}$, the secretory response to a glucose load of $1.2-1.3 \mathrm{mg} / \mathrm{ml}$ displayed a pattern comparable to that normally observed at higher glucose levels and characterized by both an early peak and a secondary build-up in the secretory rate. Taken as a whole, these findings indicate that cytochalasin $B$, in addition to increasing the velocity of the secretory mechanism at high glucose concentrations (Fig. 2), also lowers the threshold value for glucose-induced insulin release (Fig. 3 ).
At a low glucose concentration $(0.3 \mathrm{mg} / \mathrm{ml})$, cytochalasin B also significantly enhanced both the early and late secretory responses of the beta cell to gliclazide (Fig. 4). We have previously shown that cytochalasin B also enhances insulin release induced by the combination of glucose and theophylline (3). The mold metabolite might thus act on a late step in the secretory sequence and, therefore, facilitate secretion whatever insulinotropic agent is used to stimulate the beta cell.

The results illustrated in Fig. 5 are somewhat more difficult to interpret. The high rate of insulin secretion observed in the presence of cytochalasin B at a glucose concentration of $0.9 \mathrm{mg} / \mathrm{ml}$ confirms that the mold metabolite lowers the threshold value for glucose-induced insulin release. At this intermediate glucose level (0.9 $\mathrm{mg} / \mathrm{ml}$ ), cytochalasin B also markedly enhanced the total amount of insulin secreted by the beta cell during the early phase of stimulation by gliclazide. However, the increment in secretion rate attributable to gliclazide during this early phase was not significantly enhanced by the mold metabolite. This negative finding does not rule out a facilitating effect of cytochalasin B upon sulfonylurea-induced insulin secretion. Indeed, in view of current concepts concerning the dynamics of insulin release by the isolated perfused rat pancreas (9-11), it is likely that the higher rate of insulin secretion observed in the presence of cytochalasin $\mathrm{B}$ before stimulation with gliclazide provoked a partial depletion of the small pool of readily releasable insulin known to be mobilized by sulfonylureas. Such a partial depletion might conceivably have masked the facilitating action of cytochalasin $\mathrm{B}$. That the latter drug indeed enhanced the insulinotropic action of sulfonylurea in these experiments is suggested by the fact that, during the later phase of exposure to gliclazide, both the total release of insulin and the increment in secretion rate above prestimulatory level were significantly increased in the presence of cytochalasin B.

The changes in insulin secretion here observed with cytochalasin B suggest that the microfilamentous system of the beta cell plays an equally important role during both the early and later phases of insulin release. This conclusion is based on the assumption that cytochalasin $B$ acts specifically on the microfilamentous cell web of the beta cell. In previous publications from this laboratory $(3,8)$, we have already shown that such a concept is compatible with the effect of cytochalasin B upon other biological phenomena known to be dependent on the integrity of the microfilamentous system (25). The present ultrastructural observations (Figs. 6 and 7) are also compatible with such a concept. In the beta cell exposed to cytochalasin $B$, the spatial redistribution of the microfilamentous material, and the prominent margination of secretory granules, indeed all point to an alteration of the cell web, which might normally control the ac- 
cess of secretory granules to the cell membrane. Such a functional role is apparently operative during both the initial and late phases of insulin secretion.

It could be argued that cytochalasin B might affect insulin release independently of the alteration which it induces in the microfilamentous cell web. For instance, it could modify the recognition, uptake, or metabolism of glucose by the beta cell. In our opinion such an hypothesis is unlikely. Thus, cytochalasin B does not affect glucose-induced insulin biosynthesis and calcium uptake by isolated islets (3), although both of these processes are quite sensitive to alterations in glucose metabolism $(19,26)$. Therefore, the facilitating action of cytochalasin $B$ is more likely to be due to an altered response of the microtubular-microfilamentous system to the triggering action of intracellularly accumulated calcium rather than to a primary effect on glucose metabolism in the beta cell. Moreover, it was recently observed that cytochalasin $B$ inhibits the transport of several hexoses in a variety of cells (27-29). Such an inhibitory effect, even if it was to occur in the beta cell, could hardly account for an enhancement of insulin secretion.

In conclusion, the present results suggest that the microfilamentous cell web indeed participates in the dynamics of insulin release by the beta cell. It remains to be investigated whether the microtubular component of the "translocator-releasing system," as defined by Orci, Amherdt, Kanazawa, Lambert, and Stauffacher (30), is also actively involved in both the early and late phases of insulin release.

\section{ACKNOWLEDGMENTS}

We are indebted to V. Leclercq-Meyer for collaboration in the initial part of this work, and to Sidler-Ansermet, C. Van Beuren, and A. Tinant for skillful technical assistance.

This work was supported in part by grant 1180 from the Fonds voor Geneeskundig Wetenschappelijk Onderzoek (Brussels, Belgium), grant 20001 from the Fonds de la Recherche Scientifique Médicale (Brussels, Belgium), grants 3.299.70, 3.553.71, and 3.384.70 SR from the Fonds National de la Recherche Scientifique (Bern, Switzerland), the Contract of the Ministère de la Politique Scientifique (Belgium) within the framework of the Association Euratom-Universities of Brussels and Pisa, and a grant-in-aid from the Laboratoires Servier (Paris, France).

\section{REFERENCES}

1. Malaisse-Lagae, F., M. H. Greider, W. J. Malaisse, and P. E. Lacy. 1971. The stimulus-secretion coupling of glucose-induced insulin release. IV. The effect of vincristine and deuterium oxide on the microtubular system of the pancreatic $\beta$-cell. J. Coll Biol. 49: 530.

2. Malaisse, W. J., F. Malaisse-Lagae, M. O. Walker, and P. E. Lacy. 1971. The stimulus-secretion coupling of glucose-induced insulin release. V. The participation of a microtubular-microfilamentous system. Diabetes. 20 : 257.
3. Malaisse, W. J., D. L. Hager, and L. Orci. 1972. The stimulus-secretion coupling of glucose-induced insulin release. IX. The participation of the beta cell web. Diabetes. $21: 594$.

4. Lacy, P. E., S. L. Howell, D. A. Young, and C. J. Fink. 1968. New hypothesis of insulin secretion. $\mathrm{Na}$ ture (Lond.). 219: 1177.

5. Malaisse-Lagae, F., G. R. Brisson, and W. J. Malaisse. 1971. The stimulus-secretion coupling of glucose-induced insulin release. VI. Analogy between the insulinotropic mechanisms of sugars and amino acids. Horm. Metab. Res. $3: 374$.

6. Brisson, G. R., F. Malaisse-Lagae, and W. J. Malaisse. 1972. The stimulus-secretion coupling of glucose-induced insulin release. VII. A proposed site of action for adenosine-3',5'-cyclic monophosphate. J. Clin. Ine'cst. 51: 232.

7. Malaisse, W. J., M. Mahy, G. R. Brisson, and F. Malaisse-Lagae. 1972. The stimulus-secretion coupling of glucose-induced insulin release. VIII. Combined effects of glucose and sulfonylureas. Eur. J. Clin. Inv'est. 2: 85.

8. Orci, L., K. H. Gabbay, and W. J. Malaisse. 1972. Pancreatic $\beta$-cell web: its possible role in insulin secretion. Science (Wash. D. C.). 175: 1128.

9. Grodsky, G. M., L. L. Bennett, D. Smith, and K. Nemechek. 1967. The effect of tolbutamide and glucose on the timed release of insulin from the isolated perfused pancreas. In Tolbutamide...after Ten Years. W. J. H. Butterfield and W. Van Westering, editors. Excerpta Medica Foundation, Amsterdam. 11.

10. Grodsky, G. M., D. L. Curry, L. L. Bennett, and J. Rodrigo. 1968. Factors influencing different rates of insulin release in vitro. Acta Diabctol. Lat. 5(Suppl. 1): 140.

11. Grodsky, G. M., D. Curry, H. Landahl, and L. L. Bennett. 1969. Further studies on the dynamic aspects of insulin release in vitro with evidence for a two-compartmental storage system. Acta Diabctol. Lat. 6(Suppl. 1) : 554

12. Van Obberghen, E., G. Somers, G. Devis, G. D. Vaughan, F. Malaisse-Lagae, L. Orci, and W. J. Malaisse. 1972. Participation of the microfilamentous cell web in the initial secretory response of the beta cell. Diabctologia. 8: in press. (Abstr.)

13. Sussman, K. E., G. D. Vaughan, and R. F. Timmer. 1966. An in vitro method for studying insulin secretion in the perfused isolated rat pancreas. Metab. (Clin. Exp.). $15: 466$.

14. Malaisse, W., F. Malaisse-Lagae, and P. H. Wright. 1967. A new method for the measurement in vitro of pancreatic insulin secretion. Endocrinology. 80: 99.

15. Malaisse, W. J., and V. Leclercq-Meyer. 1972. Insulinotropic action of a new sulfonylurea: gliclazide. Rev. Eur. Etud. Clin. Biol. 17: 310 .

16. Hoffman, W. S. 1937. A rapid photoelectric method for the determination of glucose in blood and urine. $J$. Biol. Chem. 120: 51.

17. Wright, P. H., W. J. Malaisse, and I. J. Reynolds. 1967. Assay of partially neutralized guinea pig anti-insulin serum. Endocrinology. 81: 226.

18. Bergman, R. N., and J. Urquhart. 1971. The pilot gland approach to the study of insulin secretory dynamics. Recent Prog. Horm. Res. 27: 583.

19. Malaisse-Lagae, F., and IV. J. Malaisse. 1971. Stimulussecretion coupling of glucose-induced insulin release. III. Uptake of ${ }^{45} \mathrm{calcium}$ by isolated islets of Langerhans. Endocrinology. 88: 72.

20. Malaisse, W., and F. Malaisse-I agae. 1970. Effects of 
glycodiazin and glybenclamide upon insulin secretion in vitro. Eur. J. Pharmacol. $9: 93$.

21. Brisson, G. R., and W. J. Malaisse. 1971. Insulinotropic effect and possible mode of action of a new potent sulfonylurea (BS-4231). Can. J. Physiol. Pharmacol. 49: 536.

22. Loubatières, A., M. M. Mariani, and J. Chapal. 1970. Insulino-sécrétion étudiée sur le pancréas isolé et perfusé de rat. I. Synergie entre glucose et sulfamides hypoglycémiants. Diabetologia. 6: 457.

23. Lee, J. C., G. M. Grodsky, L. L. Bennett, D. F. SmithKyle, and L. Craw. 1970. Ultrastructure of $\beta$-cells during the dynamic response to glucose and tolbutamide in vitro. Diabetologia. 6: 542.

24. Grodsky, G. M. 1972. A threshold distribution hypothesis for packet storage of insulin and its mathematical modeling. J. Clin. Invest. $51: 2047$.

25. Wessels, N. K., B. S. Spooner, J. F. Ash, M. O. Bradley, M. A. Luduena, E. L. Taylor, J. T. Wrenn, and
K. M. Yamada. 1971. Microfilaments in cellular developmental processes. Science (Wash. D. C.). 171: 135.

26. Lin, B. J., and R. E. Haist. 1969 Insulin biosynthesis: effects of carbohydrates and related compounds. Can. J. Physiol. Pharmacol. 47 : 791.

27. Mizel, S. B., and L. Wilson. 1972. Inhibition of the transport of several hexoses in mammalian cells by cytochalasin B. J. Biol. Chem. 247: 4102.

28. Kletzien, R. F., J. F. Perdue, and A. Springer. 1972. Cytochalasin A and B inhibition of sugar uptake in cultured cells. J. Biol. Chem. 247: 2964.

29. Zigmond, S. H., and J. G. Hirsch. 1972. Cytochalasin Binhibition of D-2-deoxyglucose transport into leukocytes and fibroblasts. Science (Wash. D. C.). 176: 1432.

30. Orci, L., M. Amherdt, Y. Kanazawa, A. E. Lambert, and W. Stauffacher. 1972. Morphological events in insulin secreting cell. In Hormones Pancréatiques. Hormones de l'Eau et des Électrolytes. INSERM, Boulogne, France. 15. 